\title{
DESIGN OF WEB-BASED UYU STORE ATTENDANCE INFORMATION SYSTEM USING COLORING METHOD
}

\author{
Christy Octavius $^{1}$, Deny Hidayatullah ${ }^{2}$ \\ Sistem Informasi, Fakultas Teknologi Komunikasi dan Informasi \\ Universitas Nasional \\ https://www.unas.ac.id/ \\ christyoctavius2018@student.unas.ac.id, deny@civitas.unas.ac.id
}

(*) Corresponding Author

\begin{abstract}
Abstrak
Absensi dalam dunia kerja kadang masih melakukan cara yang manual. Di toko uyu masih ada masalah yang terjadi dalam mencatat dan membuat laporan absensi dengan manual, seperti salah dalam biodata, lupa mencatat tanggal. Dikarenakan toko uyu masih belum memakai sistem informasi absen karyawan atau staff yang terkomputeris dalam mengelola data sehingga informasi yang dapat dibutuhkan proses cukup lama dan penyimpanan tidak terjamin aman. Tujuan peneliti ini untuk membuat sistem informasi yang bisa mengelola data absensi karyawan yang bekerja di Toko Uyu yang terkomputerisasi juga mengimplementasikan metode coloring pada laporan absensi yang menghasilkan laporan berdasarkan metode pewarnaan absensi sesuai dengan jam kehadiran karyawan yang mudah dipahami. Metode ini menggunakan metode coloring sebagai solusi dari pemecahan masalah yang bisa terselesaikan pada metode greedy ialah masalah warna dan model waterfall sebagai proses pengembangan sistem yang menggunakan UML desain. Hasil yang didapatkan penelitian ini ialah sistem dapat mengoperasikan pendataan absen juga reporting data karyawan lebih efesien dan terintegrasi.
\end{abstract}

Kata kunci: Absensi Karyawan, Coloring, Waterfall, Sistem Informasi

\begin{abstract}
Attendance in the world of work is sometimes still done manually. At the Uyu shop, there are still problems that occur in recording and making attendance reports manually, such as mistakes in biodata, forgetting to record the date. Because the Uyu store still doesn't use a computerized employee or staff absence information system in managing data, so the information that can be processed is quite long and storage is not guaranteed safe. The purpose of this researcher is to create an information system that can manage attendance data for employees who work at the computerized Uyu Store and also implement a coloring method on attendance reports that generate reports based on the attendance coloring method according to employee attendance hours that are easy to understand. This method uses the coloring method as a solution to solving problems that can be solved in the greedy method, namely the color problem and the waterfall model as a system development process that uses UML design. The result of this research is that the system can operate attendance data collection as well as report employee data more efficiently and integrated. Keywords: Employee Attendance, Coloring, Waterfall, System Information
\end{abstract}

\section{INTRODUCTION}

Attendance is an activity that is very important for continuity in payroll, the calculation of employee absenteeism is determined by the number of work attendance which will be a process that requires supervision in recording attendance data (Pradnyana and Brahma 2020). There is still a lot of absenteeism in the world of work still using the manual method using an attendance record book Julianc (Wibawa 2017). Employee attendance is also an important factor in an agency as an achievement goal, it also has an impact on the performance of each employee (Satrya, Muryati, and Ningsih 2021). The company needs to monitor the recording and reporting of employee attendance data, such as arriving on time or being late (Triyono, Safitri, and Gunawan 2018)

At Uyu Store the employees still record attendance manually, namely using an attendance record book (Indrayuni 2018). As a result of such obstacles, it will often lead to errors in recording and loss of unwanted attendance data (Indra et al. 2019). In this case, the absence application that is still manual will cause problems such as employees being able to manipulate attendance data so that what should get a pay cut does not happen (Henny et al. 2018). 
Coloring is coloring labels in the minimum number of colors needed without conflict between nodes (Saif and Mussafi 2015). An information system is needed in conducting attendance that plays a role in computerized data management that implements good control and makes it easier to build historical. Data can directly monitor the activities of employees as well as attendance reports will be updated automatically (Subiantoro and Sardiarinto 2018). Toko Uyu itself is a shop that is engaged in the snack food business. Various kinds of snacks are sold, such as cassava chips, spicy chips, pastries, and other dry foods. Uyu store has also opened its business in various online shop apk.

In designing the Uyu store attendance information system in storing the attendance data into the database, it is arranged in such a way as to make it easier if at any time the store needs It (Setyabudhi 2017).

Research conducted (Saif and Mussafi 2015). Implementing the greedy coloring algorithm in determining the coloring of the Yogyakarta City map. Research conducted (Putra Fhonna et al. 2020). Describes the design of an attendance information system that is designed out of necessity and to make it easier for users to recapitulate attendance. The research was conducted (Roosdianto, Sari, and Satriansyah 2021). Describes the attendance design to facilitate the processing of absences to minimize unwanted risks.

Currently, Uyu Store is still recording attendance manually using the attendance record book, so a gap analysis is needed which aims to find out whether the system is as expected according to the Gap measurement. Here are the gaps found.

Table 1. Gap Analysis

\begin{tabular}{|c|c|c|c|c|c|c|}
\hline \multirow{2}{*}{$\begin{array}{c}\text { No } \\
\text {. }\end{array}$} & \multirow{2}{*}{$\begin{array}{c}\text { ProcessRequirment } \\
\text { ofabsentsystem }\end{array}$} & \multirow[t]{2}{*}{ Gap desc } & \multicolumn{3}{|c|}{ fulfillment } & \multirow[b]{2}{*}{ Resolution } \\
\hline & & & $\mathrm{N}$ & $\mathrm{P}$ & $\mathrm{F}$ & \\
\hline 1 & $\begin{array}{l}\text { Collecting absent } \\
\text { employee }\end{array}$ & $\begin{array}{l}\text { Requiredabsenteeism } \\
\text { data storage systems }\end{array}$ & & & $\sqrt{ }$ & $\begin{array}{l}\text { For attendance data storage } \\
\text { will be stored into the } \\
\text { database PHPMyAdmin }\end{array}$ \\
\hline 2 & attendance & $\begin{array}{l}\text { Required employee } \\
\text { attendance by the delay } \\
\text { or timeliness }\end{array}$ & & & $\sqrt{ }$ & $\begin{array}{l}\text { Using the method of coloring } \\
\text { in which every employee time } \\
\text { attendance data will be } \\
\text { summarized in a different } \\
\text { color. }\end{array}$ \\
\hline 3 & Report Data & $\begin{array}{l}\text { Required employee } \\
\text { attendance data report } \\
\text { showing the form of the } \\
\text { report is automatically } \\
\text { printed out }\end{array}$ & & & $\sqrt{ }$ & $\begin{array}{l}\text { In bother printing the data } \\
\text { will be a menu report/export } \\
\text { attendance data } \\
\text { automatically. }\end{array}$ \\
\hline
\end{tabular}

\section{RESEARCH METHODOLOGY}

\section{Type of}

Research This study used a qualitative approach and applied research.

\section{Target/Research Subject The}

the target of this research is the employees of Toko Uyu.

\section{Data Collection Techniques}

In conducting this research, there are data and information used in processing the data collection as follows:

1. Observation

At this stage studying the problems that exist in the field and research objects regarding the employee system handling system.

2. Interview At
At this stage, the researcher asked for complete information from the Uyu Store as data collection, which directly asked the owner of the Uyu Store.

3. Literature study.

This stage looks for materials that support the definition of problems through the internet and journals related to attendance problems.

\section{System Development Model}

In this Uyu Store, an attendance design system was built using the waterfall model as a system development process that uses UML design. Then in this method uses the coloring method as a solution to solving problems that can be solved in the greedy method is the color problem. The greedy method itself is a way of designing an algorithm (Rahadi 2019). 
In the graph, coloring processes the color label of each vertex so that no two neighboring vertices have the same color (Anwar, Sari, and Informatika 2019). This coloring method is implemented in reporting attendance data late or on-time attendance by color. In this attendance coloring method, only 2 colorings are used, namely red and green. There is picture 1 where red is for late attendance and green is for punctual attendance.

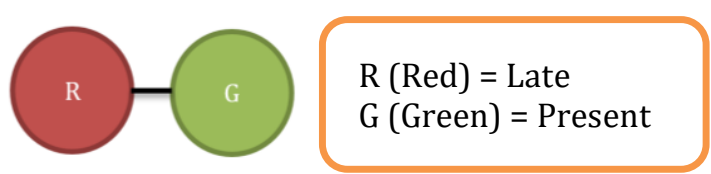

Figure 1. Color nodes of research sources

\section{RESULTS AND DISCUSSION}

\section{Needs Analysis.}

At this stage it contains the stages of the functional requirements process for the Uyu Store attendance system, namely:

1. Admin

Admin can manage employees. attendance data Admin can recap employee attendance data. Admin can manage employee delay data

2. Employees

Employees can input their attendance data process during working hours.

\section{Flowchart Coloring Method}

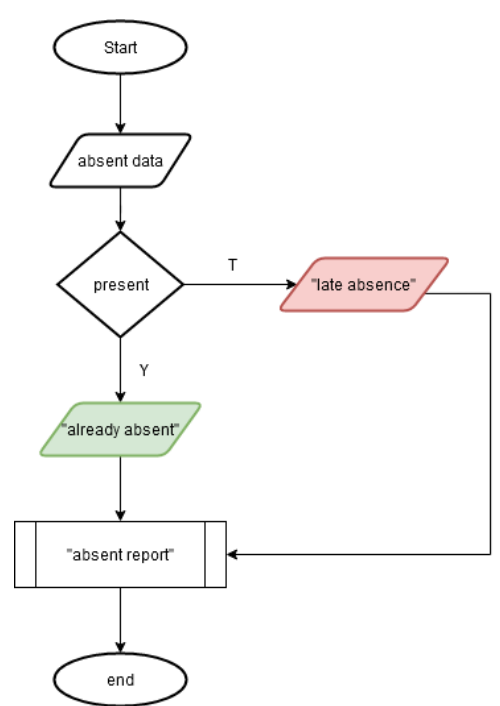

Figure 2. Flowchart coloring method

Algorithm:

- Input absent data that has been saved and then processed into a sub-unit program
- If the absent employee data is present on time then follow the Y/Yes arrow

- If the absent data is late then the condition is not met will follow the direction N/No

\section{Use Case Diagram This}

use case explains how employees and admins interact through the system. Figure 3 is a picture of where a system of manufacturing programs will be created.
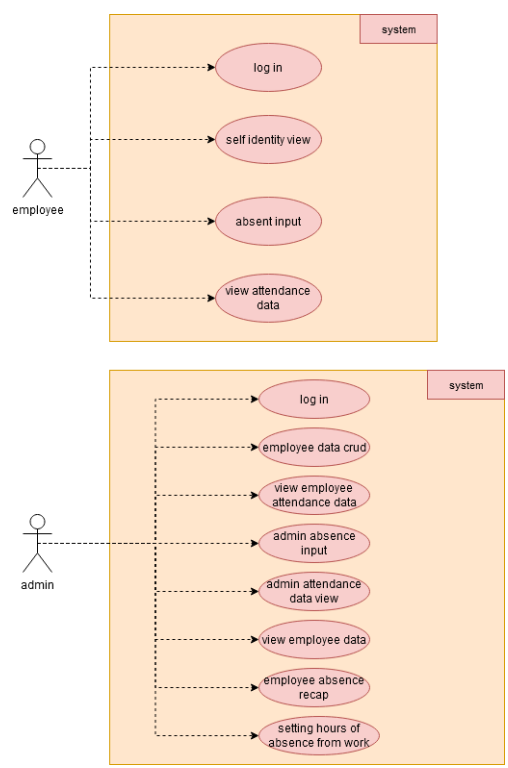

Figure 3. Use Case Interaction Attendance System

\section{Activity Diagram The}

The activity diagram is described in Figure 4 where this system visualizes where employees input attendance which is processed by the system and managed by the admin.

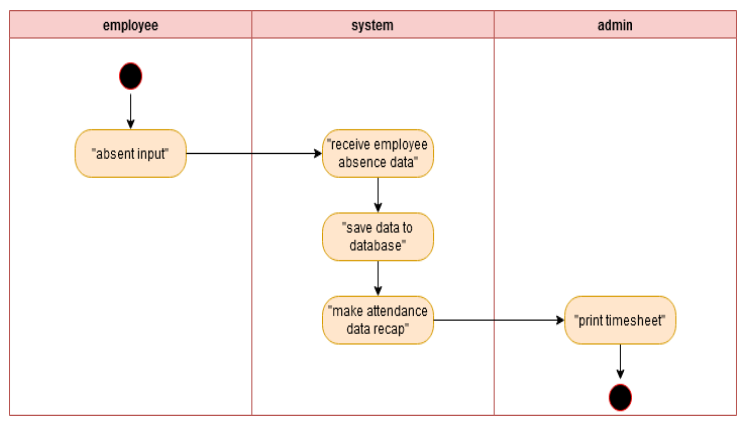

Figure 4. Activity Attendance

\section{Sequence Diagram The}

The sequence diagram in Figure 5 illustrates the process of storing employee absent data in a system. 


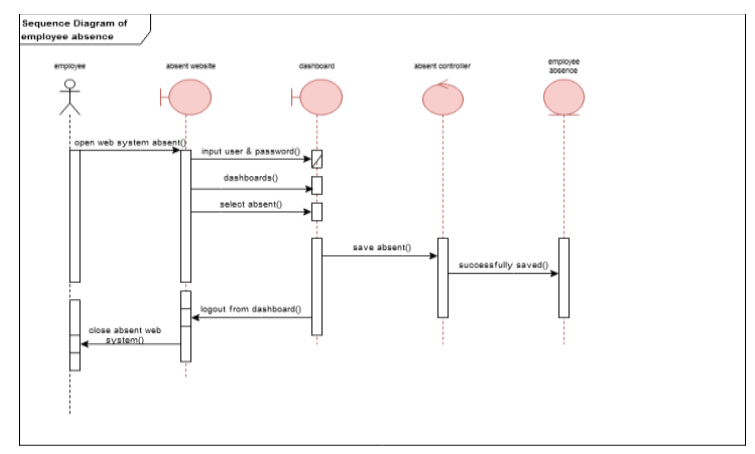

Figure 5. Sequence Flow Attendance System

\section{Database Design}

\section{Entity Relationship}

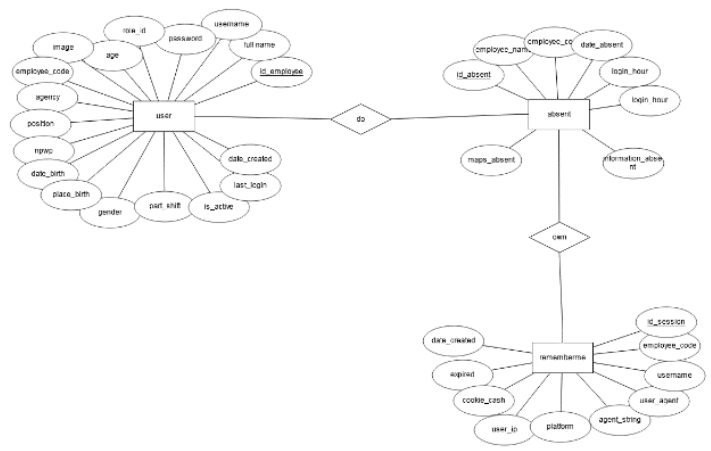

Figure 6. Entity Relationship

Figure 6 depicts the entity-relationship database Uyu store, wherein the database design there is a user entity that contains employee and admin identities, then there is an absent entity as attendance data collection and remember me as storage of login information.

\section{Implementation}

a. Form Login

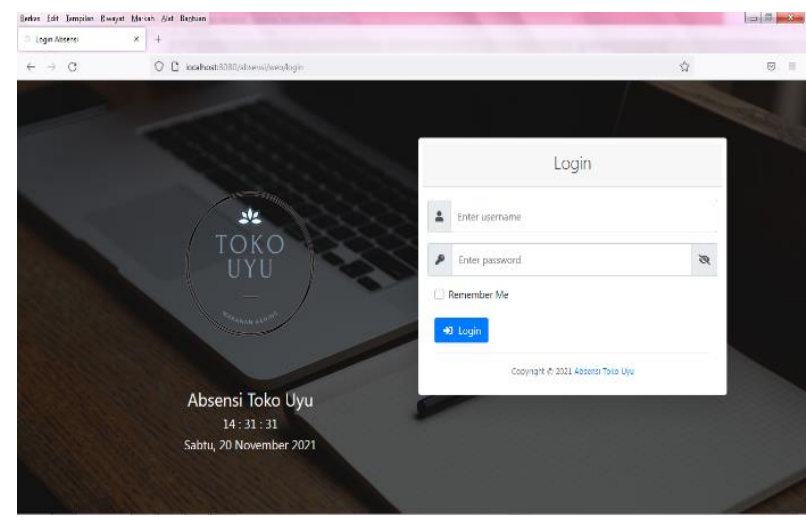

Figure 7. Login Display
Figure 7 shows a login section, on the results of the login image, employees and admins can enter their respective usernames and passwords that have been created by the admin to enter the dashboard form.

\section{b. Admin Dashboard Form}

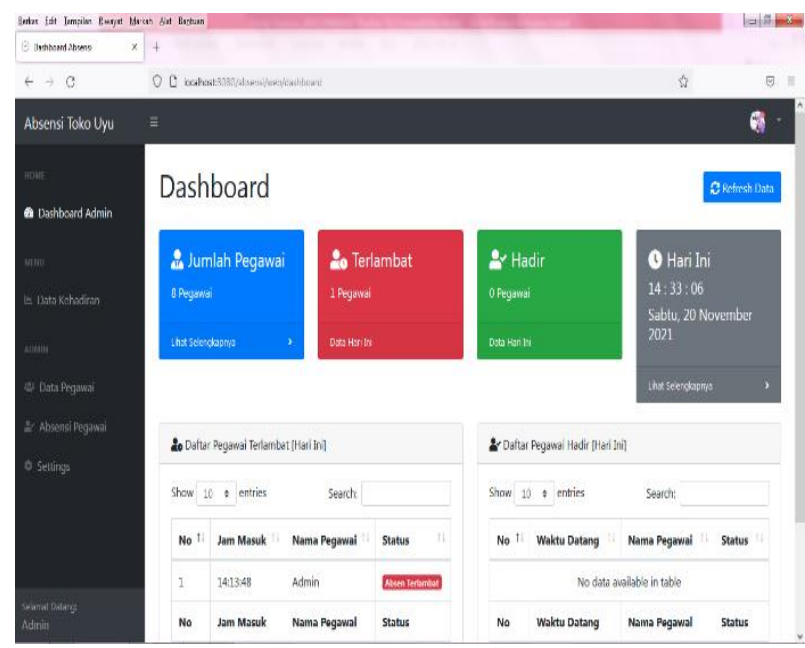

Figure 8. Admin dashboard

Figure 8 shows an overview of the admin dashboard, where the admin can check the attendance of employees who are late or on time. There are already individual data forms that directly display the number of employees present. Below it there is also an input table for the employee attendance list.

\section{c. Attendance input form \& admin identityAdmin}

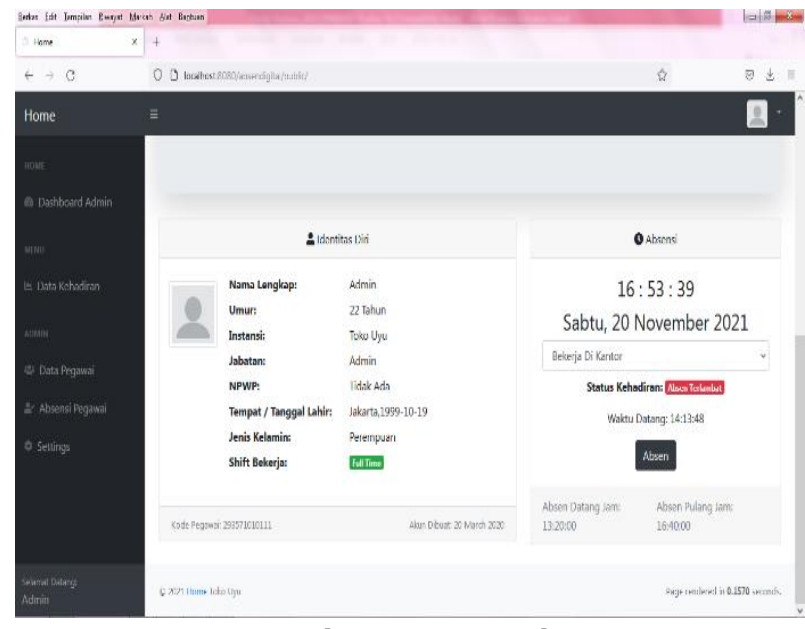

Figure 9.identity \& attendance

Figure 9 shows the identity along with photos and the appearance of inputting absenteeism on the admin. In inputting absences, there is also an 
automatic feature for late and on-time attendance by determining color.

d. Attendance Form

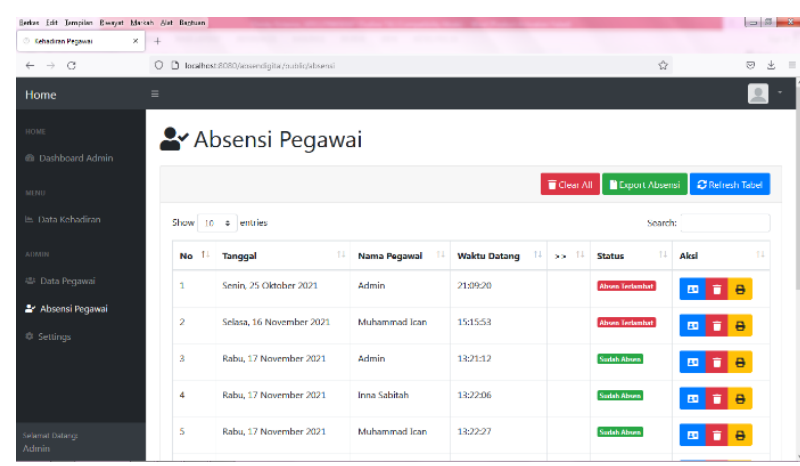

Figure 10. Attendance

Figure 10 displays the results of data input for employees who have made attendance. In this view the admin can recap employee data. Here you can see coloring late and on time.

e. The results of the recapitulation of absenteeism

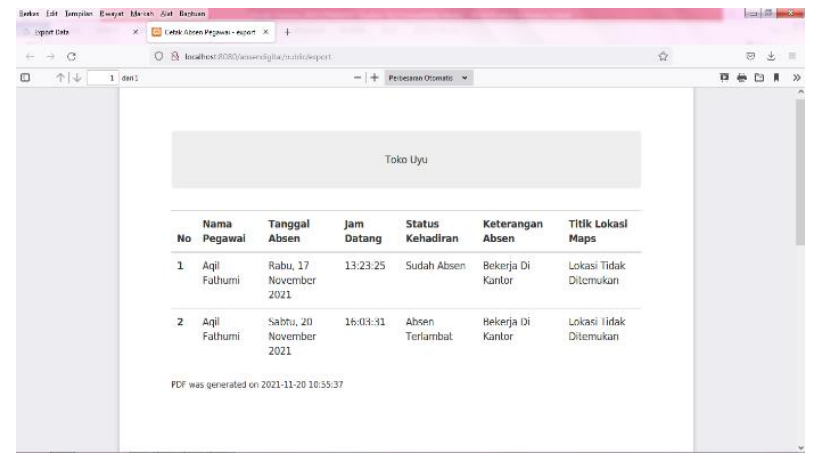

Figure 11. The results of the recapitulation of $p d f$. Figure 11 shows the results of the recap of the employee's attendance data in pdf. f. Employee Dashboard Form.

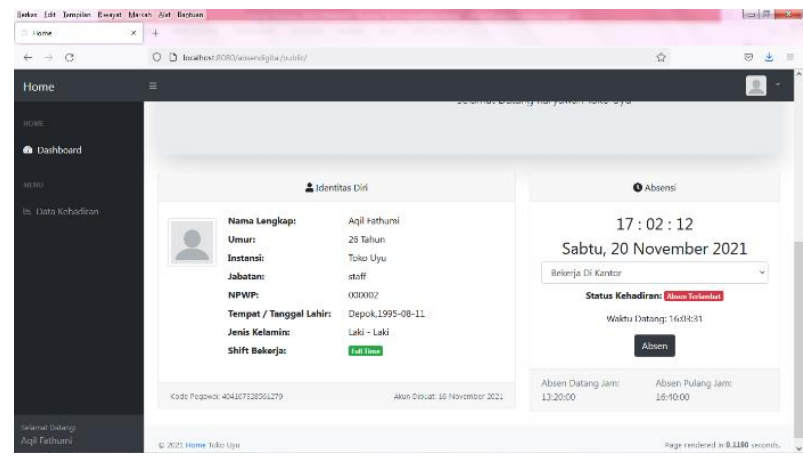

Figure 12. Identity \& attendance of employees

Figure 12 employees can see their identity and input attendance according to the time specified by the admin.

g. Employee attendance form

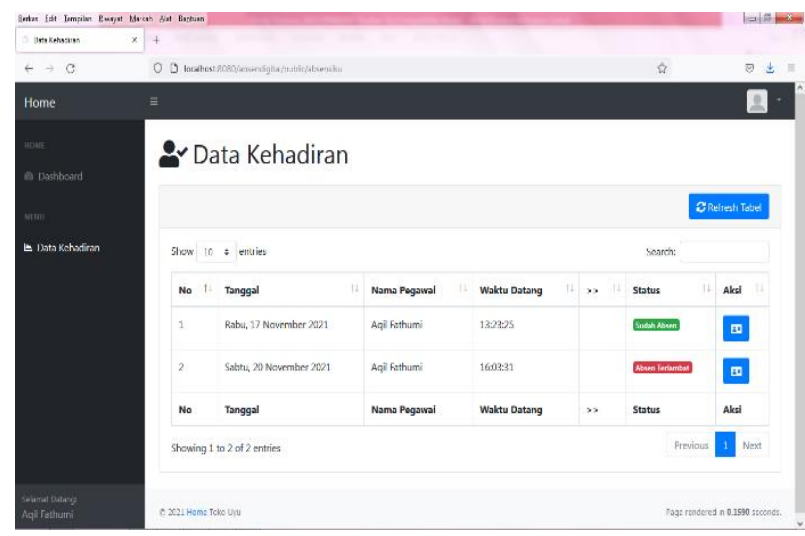

Figure 13. Employee attendance data

In Figure 13 here employees can see their attendance data, so not only admins can check but employees can also access their attendance data.

\section{Testing Results}

Table 2. Functional Requirements

\begin{tabular}{|c|c|c|c|c|c|c|}
\hline Functional Requirements & User 1 & User 2 & User 3 & User 4 & User 5 & User 6 \\
\hline System absences do & $\sqrt{ }$ & $\sqrt{ }$ & $\sqrt{ }$ & $\sqrt{ }$ & $\sqrt{ }$ & $\sqrt{ }$ \\
\hline $\begin{array}{l}\text { The system can print absent export } \\
\text { data into pdf/excel }\end{array}$ & $\sqrt{ }$ & $\sqrt{ }$ & $\sqrt{ }$ & $\sqrt{ }$ & $\sqrt{ }$ & $\sqrt{ }$ \\
\hline $\begin{array}{l}\text { enter absent based coloring late / on } \\
\text { time }\end{array}$ & $\sqrt{ }$ & $\sqrt{ }$ & $\sqrt{ }$ & $\sqrt{ }$ & $\sqrt{ }$ & $\sqrt{ }$ \\
\hline $\begin{array}{l}\text { system of storage of the data can be } \\
\text { absent }\end{array}$ & $\sqrt{ }$ & $\sqrt{ }$ & $\sqrt{ }$ & $\sqrt{ }$ & $\sqrt{ }$ & $\sqrt{ }$ \\
\hline
\end{tabular}

The test results attendance system that uses Functional Requirements concluded if the results are accurate in the development of the online attendance system required by the user. 


\section{White Box}

White box testing is intended as a guide to producing the correct program as a whole so that the designed system can output as needed. The following white box testing was carried out:

a. $\quad \mathrm{V}(\mathrm{G})=\mathrm{E}-\mathrm{N}+2$ where the results are the same as $V(G)=P+1$.

b. The flowgraph has the same region as the number of $V(G)$ then the system is declared to be proven to be efficient and effective.

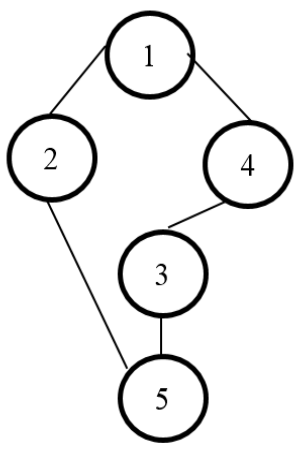

Figure 14. Flowgraph Nation Key

Region $(\mathrm{R})=1$

Node $(\mathrm{N})=5$

Edge $(\mathrm{E})=5$

Predicate Node $(\mathrm{P})=1$

Key Figure 14:

Node 1: the process of calling user and password data from database

Node 2: checking the input username and password Node 3: valid username and password

Note 4: checking the suitability of the username and password

Note 5: the results of the login process

\section{CONCLUSIONS AND SUGGESTIONS}

\section{Conclusion}

In conclusion, the design of this attendance website application is to make it easier for Uyu store employees to take attendance online. This attendance application also helps in inputting employee attendance data collection and recording attendance systematically which is useful for storing employee data more safely and efficiently, so Uyu store employees do not need to use manual methods anymore.

\section{Suggestions}

Based on the conclusions above, to develop a website-based attendance information system, it is better for an absence system to only make arrival times, it is expected to be developed in making employee return times and the absence system can be developed by adding a QR Code,

\section{REFERENCES}

Anwar, Syaiful, Ni Nengah Devita Sari, and Frans Eduard Schaduw - Universitas Bina Sarana Informatika. 2019. "Aplikasi Laporan Kehadiran Berbasis Web Pada Mini Market Menggunakan Metode Coloring." IJNS Indonesian Journal on Networking and Security $8(3)$.

http://ijns.org/journal/index.php/ijns/articl e/view/1594 (December 25, 2021).

Henny, T, Febriana Harumy, Julham Sitorus, and Meliza Lubis. 2018. "Sistem Informasi Absensi Pada Pt. Cospar Sentosa Jaya Menggunakan Bahasa Pemprograman Java." Jurnal Teknik dan Informatika 5(1): 63-70. https://jurnal.pancabudi.ac.id/index.php/Jut i/article/view/95 (December 25, 2021).

Indra, Evta, M Diarmansyah Batubara, Muhammad Yasir, and Sugandi Chau. 2019. "Desain Dan Implementasi Sistem Absensi Mahasiswa Berdasarkan Fitur Pengenalan Wajah Dengan Menggunakan Metode Haar-Like Feature: Sistem Informasi." Jurnal Teknologi Dan Ilmu Komputer Prima (JUTIKOMP) 2(2): 363-70. http://jurnal.unprimdn.ac.id/index.php/JUTI KOMP/article/view/637 (December 21, 2021).

Indrayuni, Elly. 2018. "Website Pengolahan Absensi Dan Gaji Pegawai Menggunakan Metode Waterfall." BINA INSANI ICT JOURNAL 5(1): 21-30. http://www.ejournalbinainsani.ac.id/index.php/BIICT/article/vie w/878 (December 21, 2021).

Pradnyana, Gede Aditra, and A.A. Gede Raka Wahyu Brahma. 2020. "Pengembangan Sistem Informasi Monitoring Kehadiran Dosen Secara Realtime Berbasis Web." IJNSE (International Journal of Natural Sciences and Engineering) Volume 4,: 11-20.

Putra Fhonna, Rizky et al. 2020. "SISTEM Informasi Absensi Pegawai Pada Biro Kominfo Kantor Bupati Kabupaten Aceh Utara Berbasis Web." Jurnal Ilmu Komputer dan Sistem Informasi (JIKOMSI) 3(1.1): 333-40. http://ejournal.sisfokomtek.org/index.php/ji kom/article/view/127 (December 25, 2021).

Rahadi, Andi Pujo. 2019. "Penjadwalan Mata Kuliah Menggunakan Pewarnaan Graf Dengan Algoritma Largest First." Jurnal Padegogik 2(1): $\quad 1-13$. https://jurnal.unai.edu/index.php/jpd/articl 
e/view/1067 (December 25, 2021).

Roosdianto, Rully, Ani Oktarini Sari, and Arief Satriansyah. 2021. "Rancang Bangun Aplikasi Sistem Informasi Absensi Karyawan Online." INTI Nusa Mandiri 15(2): 135-42. http://ejournal.nusamandiri.ac.id/index.php /inti/article/view/1932 (December 25, 2021).

Saif, Noor, and Muhammad Mussafi. 2015. "Penerapan Greedy Coloring Algorithm Pada Peta Kotamadya Yogyakarta Berbasis FourColour Theorem." Kaunia: Integration and Interconnection Islam and Science 11(1): 1926. http://ejournal.uinsuka.ac.id/saintek/kaunia/article/view/107 8 (December 25, 2021).

Satrya, Angga, Muryati Muryati, and Yulia Istia Ningsih. 2021. "Analisis Tingkat Kehadiran Pegawai Dengan Aplikasi Sikepo Di Dinas Tanaman Pangan Dan Hortikultura Kabupaten Batang Hari." JURNAL MAHASISWA 1(1): $\quad 9-21$. http://jurnal-citraekonomi.com/index.php/jurnalmhs/article/ view/78 (December 28, 2021).

Setyabudhi, Albertus Laurensius. 2017. "Perancangan Sistem Informasi Pengolahan Data Absensi Dan Pengambilan Surat Cuti Kerja Berbasis Web." JR: Jurnal Responsive Teknik Informatika 1(01): 11-22. http://ojs3.lppmuis.org/index.php/JR/article/view/213 (December 25, 2021).

Subiantoro, Subiantoro, and Sardiarinto Sardiarinto. 2018. "Perancangan Sistem Absensi Pegawai Berbasis Web Studi Kasus: Kantor Kecamatan Purwodadi." Jurnal Swabumi 6(2): 184-89. https://ejournal.bsi.ac.id/ejurnal/index.php/ swabumi/article/view/4868.

Triyono, Triyono, Rosiana Safitri, and Taufik Gunawan. 2018. "Perancangan Sistem Informasi Absensi Guru Dan Staff Pada SMK Pancakarya Tangerang Berbasis Web." Journal Sensi 4(2): 153-67.

Wibawa, Julian Chandra. 2017. "Rancang Bangun Sistem Informasi Akademik (Studi Kasus: SMPIT Nurul Islam Tengaran)." Infotronik: Jurnal Teknologi Informasi dan Elektronika 2(2): $\quad$ 75-84. http://183.91.79.105/index.php/infotronik/ article/view/33. 
P-ISSN: 2656-1743 | E-ISSN: 2656-1735

JURNAL RISET INFORMATIKA

DOI: https://doi.org/10.34288/jri.v4i1289.

Vol. 4, No. 1 December 2021 